\title{
Tracked vehicle impacts to vegetation structure and soil erodibility
}

\author{
WILLIAM P. GRANTHAM, EDWARD F. REDENTE, CALVIN F. BAGLEY, AND MARK W. PASCHKE
}

Authors are graduate research assistant and professor, Department of Rangeland Ecosystem Science; associate director, Center for Ecological Management of Military Lands (CEMML); and research scientist, Department of Rangeland Ecosystem Science, Colorado State University, Fort Collins, Colo. 80523.

\begin{abstract}
There has been increasing concern that training on military lands results in excessive soil erosion, ecosystem degradation, and loss of sustainable training resources. Vegetation structure has been shown to play a role in soil surface stabilization by reducing shear stress caused by wind force. A study at the Idaho Army National Guard training facility at Orchard Training Area (OTA), Ida. assessed the effect of simulated M1A2 Abrams battletank maneuvers on grassland plant canopies and soil erodibility. The point-intercept method was used to estimate vertical vegetation structure before and after tracking. A portable wind tunnel was used to measure threshold wind speeds (TWS) associated with different numbers of tank passes and soil mass removed by wind. Results indicated that significant damage occurred to vertical vegetation structure as the number of passes increased. Threshold wind speed, an indicator of soil surface stability, significantly decreased with tracking and eroded soil mass significantly increased. Positive correlations existed between vegetation parameters and threshold wind speed. Soil loss was negatively correlated with vegetation parameters. Results indicated that the decrease of vertical vegetation structure led to a decrease in threshold wind speed. This decrease in threshold wind speed was the result of reduced soil surface protection by vegetation. Decreased surface protection also resulted in increased soil loss. Results from this work confirmed that vegetation plays a major role in reducing shear stress on the soil surface. Predictions for soil loss at Orchard Training Area resulting from the number of M1A2 passes are made using linear models. A critical tracking threshold of 4 passes was estimated based upon model output and average local wind speeds for Orchard Training Area.
\end{abstract}

Key Words: Erosion, threshold friction velocity, threshold wind speed, arid lands, surface roughness, military lands, wind tunnels

Wind erosion typically removes the most productive layers of the soil from the upper surface horizons. Loss of soil from the upper horizons has the potential to reduce productivity, change vegetation species composition, degrade land conditions, and contribute to increased rates of desertification. There has been

Research was funded through the Center for Ecological Management of Military Lands (CEMML), by the Idaho Army National Guard, the U.S. Army Corps of Engineers Construction Engineering Laboratory, and the U.S. Forest Service Rocky Mountain Experiment Station.

Manuscript accepted 8 Dec. 2000

\section{Resumen}

Ha habido una preocupación creciente respecto a que el entrenamiento en campos militares resulte en una excesiva erosión de suelo, degradación de los ecosistemas y perdida de los recursos sustentables de entrenamiento. La estructura de la vegetación ha mostrado jugar un papel en la estabilización de la superficie del suelo al reducir el estrés cortante causado por la fuerza del viento. Un estudio realizado en el área "Orchard" (AEO) de las instalaciones de entrenamiento de la Guardia Nacional situadas en Idaho evaluó el efecto de maniobras simuladas del tanque de batalla MIA2 Abrams sobre la copa de las plantas de pastizal y la susceptibilidad a erosión del suelo. Se utilizo el método de intercepción de puntos para estimar la estructura vertical de la vegetación antes y después del paso de los tanques. Un túnel de viento portátil se utilizó para medir el umbral de la velocidad del viento (UVV) asociado con diferentes números de pasos del tanque y la masa de suelo removida por el viento. Los resultados indican que conforme el número de pasos aumento ocurrió un daño significativo de Ia estructura vertical de la vegetación. El umbral de la velocidad del viento, un indicador de la estabilidad de la superficie del suelo, disminuyo significativamente con el paso de los tanques y la masa de suelo erosionado aumento significativamente. Existieron correlaciones positivas entre los parámetros de la vegetación y los umbrales de velocidad del viento. La pérdida de suelo se correlaciono negativamente con los parámetros de la vegetación. Los resultados indican que la disminución en la estructura vertical de la vegetación conduce a una disminución del umbral de la velocidad del viento. Esta disminución en el umbral de la velocidad del viento fue el resultado de una reducida protección de la superficie del suelo por la vegetación lo que también resultó en un incremento de pérdida de suelo. Los resultados de este trabajo confirman que la vegetación juega un papel principal en reducir el estrés cortante en la superficie del suelo. Las predicciones para la perdida de suelo en el área de entrenamiento "Orchard" resultantes del número de pasos del MIA2 son hechas utilizando modelos lineales. Se estimo un umbral crítico de 4 pasos de tanque, el cual fue basado en el modelo resultante y el promedio local de velocidad del viento de la área de entrenamiento "Orchard".

increasing concern that training activities on military lands result in excessive soil erosion, ecosystem degradation, and loss of sustainable training resources. The National Environmental Policy Act of 1969 (NEPA) requires that the Army minimize ecological impacts caused by military training activities to the 4.8 million 
hectares of land for which it is responsible. Soil conservation is a critical first step for maintaining ecosystem productivity.

Wind erosion of soils occurs when the force of drag is sufficient to overcome the forces holding soil particles in place such as gravity, soil moisture, and surface crust aggregation (Bagnold 1941). The term threshold friction velocity (TFV), which corresponds to the minimum surface drag associated with a wind velocity at a particular height needed to overcome forces holding soil particles in place, originated from Bagnold's work and is used as an indicator of soil surface stability (Bagnold 1941). Estimation of dust production, wind erosion, and soil surface stability relies heavily on values of TFV (Gillette et al. 1980) and is influenced by the amount of surface roughness present (Marshall 1971, Gillette 1988, Gillette and Stockton 1989, Stockton and Gillette 1990, Musick and Gillette 1990). Threshold friction velocities and the effects of roughness elements have been determined experimentally by several investigators with the use of laboratory wind tunnels (Bagnold 1941, Chepil 1945, Iversen et al. 1973, Wood et al. 1974, Phillips 1980). Threshold wind speed is a similar indicator of soil surface stability, which refers to the speed at a particular height above the soil surface at which soil particle entrainment begins. Experiments examining soil loss have been done by inserting soil traps or filters at the rear of wind tunnels to capture eroding particles (Chepil 1956, Lyles and Schrandt 1974, Fryrear 1985, Findlater et al. 1990, Williams et al. 1995).

Previous work using wind tunnels, soil traps, and field observations has shown that surface crusting on the soil surface and vertical vegetation structure act as aerodynamic roughness elements. Marshall (1971), Gillette and Stockton (1989), Musick and Gillette (1990), and Raupach et al. (1993) concluded that vertical vegetation structure acts as an aerodynamic roughness element with respect to the airstream. Their work indicated that overall shear stress caused by wind passing over a roughened surface is partitioned between stress on the roughness elements and stress on the soil surface. These individual elements decrease the wind stress on the erodible surface by absorbing a significant portion of the downward momentum flux from the airflow above.

The purpose of this research was to assess the effect of military training equipment on vegetation structure and subsequent erodibility of soils. The specific objectives of this study were to: 1) quanti- fy how the M1A2 Abrams battletank impacts the vegetation structure of semiarid grasslands and how this may contribute to increased wind erodibility of soils, and 2) determine if a critical tracking threshold exists that significantly decreases surface stability and increases soil loss. Within the framework of these objectives we tested 2 hypotheses: 1) tracked and non-tracked sites will have differences in bare ground, ground covered by litter, vertical vegetation structure, threshold wind speed, and amount of soil removed, and 2) tracking intensities will produce significant differences in bare ground, ground covered by litter, vertical vegetation structure, threshold wind speed, and amount of soil removed.

\section{Materials and Methods}

\section{Site Description}

Research was conducted at the Idaho Army National Guard (IDARNG) training facilities at Orchard Training Area, Ida (OTA). This is an Army National Guard Training facility located in southwestern Idaho on the Snake River Plain $\left(43^{\circ} 18.9^{\prime}\right.$ $\mathrm{N}, 116^{\circ} 01.7^{\prime} \mathrm{W}$ ) which currently experiences soil losses during and following training activities. This soil loss is an ecological concern as well as a safety issue. Dust storms from disturbed soils reduce visibility and hamper training activities. The soils in the area are aridisols that developed in loess or silty alluvium deposited over basalt plains.

\section{Experimental Design}

A complete randomized block design was used to study the impacts of M1A2 maneuvers on the vegetation and soil surface. Three blocks were selected within the northern vegetation zone of Orchard Training Area for each of the randomized blocks. The locations for the blocks were based on similarity in soil surface texture, homogeneity in vegetation structure, and lack of previous tracked vehicle disturbance. Each block measured 100 meters long, 50 meters wide, and contained 5 treatments.

Tracking treatments were applied in all 3 blocks in August 1996 to simulate tracked vehicle maneuvers. The treatments consisted of a control, which received no passes, and treatments, which received 1 , 2,4 , or 8 consecutive passes. Each M1 pass was straight and occurred at approximately 30 miles per hour. Turns were not simulated. Specifications for the M1 are shown in Table 1.
Table 1. Vehicle specifications for the M1A2 (Foss 1988).

\begin{tabular}{lc}
\hline \hline Category & Specifications \\
\hline Crew & 4 \\
Combat Weight & $57,154 \mathrm{~kg}$ \\
Ground Pressure & $0.96 \mathrm{~kg} \mathrm{~cm}^{-2}$ \\
Length & $7.9 \mathrm{~m}$ \\
Ground Clearance & hull center $-0.48 \mathrm{~m}$ \\
& hull sides $-0.43 \mathrm{~m}$ \\
Single Track Width & $0.64 \mathrm{~m}$ \\
\hline
\end{tabular}

Vegetation sampling was conducted in July and August 1996. Four vegetation parameters were measured pre- and posttracking to document the baseline vegetation and soil surface conditions. The 4 vegetation parameters measured were percent cover by species, fractional bare ground, fractional litter cover, and fractional aerial intercept per plot. Each treatment within a given block was designated as a plot. Within each of these plots, two, 50-meter transects were located within the area that was to be impacted by the M1 treads. Each-50 meter transect was sampled using the point-intercept method as described by Bonham (1989) at 1-meter intervals.

A portable wind tunnel was used to measure threshold wind speed and soil loss. Threshold wind speed is defined as the wind speed $\left.(\mathrm{m} \mathrm{sec})^{-1}\right)$ at a particular height above the soil surface at which soil particle entrainment within the airstream is observable. It is also used as an indicator of soil surface stability. Soil loss was estimated with the use of inline filters inserted at the rear of the wind tunnel. These filters trapped soil and litter particles removed from the surface by the wind stream which were later separated into litter and soil components and weighed. It should also be noted that the fine dust component of the sampled soils was not captured by the furnace filters and was not quantified.

Wind Tunnel Design: The portable wind tunnel used was the same as the one described by Gillette (1978), Gillette et al. (1980), Williams et al. (1995), and similar to that used by Marticorena et al., (1997). This open-floored wind tunnel was built so that a variable speed turbulent boundary layer could be formed over a flat soil containing small-scale roughness elements. The wind tunnel used a 2-dimensional, 5:1 contraction section with a honeycomb flow straightener, a working section where wind speed was measured, a rectangular diffuser chamber, and a filter box. Dimensions of the cross section of the working section were $15.24 \mathrm{~cm} \times$ $15.24 \mathrm{~cm}$ and the length was $300.5 \mathrm{~cm}$. 
Wind speed was measured with a pitot tube located $20 \mathrm{~cm}$ from the rear of the working section. The filter box was $33 \mathrm{x}$ $33 \mathrm{~cm}$ and contained 2 filters of different densities held in place by metal grates and was located at the rear of the expansion chamber. The filter material consisted of $30 \times 30-\mathrm{cm}$ fine furnace filter and coarse furnace filter to capture litter and soil removed from the surface.

Wind tunnel tests were performed after tracking. A wind tunnel trial consisted of the threshold wind speed measurements and the soil removal measurements. Threshold wind speed tests were measured first by placing the wind tunnel on the plo and slowly increasing the wind speed within the working section until particle entrainment was visible. The wind speed was then held constant while wind velocity measurements were taken at 5 consistent heights at the rear of the tunnel. These heights were at the surface, $37.5 \mathrm{~mm}, 75$ $\mathrm{mm}, 112.5 \mathrm{~mm}$, and $150 \mathrm{~mm}$ above the soil surface. Threshold wind speed measurements from the $75 \mathrm{~mm}$ height were used as threshold wind speed data for this study.

The wind speed was then increased to the full capacity of the wind tunnel and held constant for 5 minutes to collect removable surface material in the inline filters. The wind tunnel was then shut down. The filters containing wind blown litter and soil were collected and placed into a bag. The bagged filters were taken to a laboratory where collected soil was shaken out of the filters, litter components were picked from the filters, and materials in the bag were combined and weighed. Wind blown litter and soil were then sieved into 3 size classes and weighed separately. These size classes were coarse litter, fine material (fine litter and coarse soil fragments), and soil. This procedure was repeated for all 150 plots ( 3 blocks $\times 5$ treatments $\times 10$ wind tumnel plots).

\section{Statistical Analysis \\ Vegetation Parameters}

Pre-tracking multiple comparisons of parameter means were done to determine if vegetation measurements were homogeneous among blocks and among treatments. It was found that there were significant pre-tracking differences among blocks for species composition and fractional aerial intercept. This prompted the examination of the change in each vegetation parameter that resulted from a treatment instead of just an examination of post-tracking vegetation parameters. Posttracking fractional aerial intercept was

Table 2. Percent cover by species for total study site and by block.

\begin{tabular}{|c|c|c|c|c|c|}
\hline Species & Lifeform $^{1}$ & Overall & Block 1 & Block 2 & Block 3 \\
\hline & \multicolumn{5}{|c|}{$(\ldots \ldots \ldots$ (\% cover $) \cdots \ldots \ldots$} \\
\hline Bromus tectorum & IAG & 18 & 23 & 14 & 22 \\
\hline Epilobium paniculatum & NAF & 13 & 13 & 21 & 5 \\
\hline Lagophylla ramosissima & NAF & $<1$ & 1 & 0 & 0 \\
\hline Lepidium perfoliatum & IAF & 18 & 16 & 16 & 27 \\
\hline Poa secunda & NPG & 23 & 16 & 18 & 0 \\
\hline Ranunculus testiculatus & IAF & 4 & $<1$ & $<1$ & 14 \\
\hline Salsola kali & IAF & 5 & 0 & 0 & 20 \\
\hline Sitanion hystrix & NPG & 7 & 4 & 10 & 11 \\
\hline Vulpia octoflora & $\mathrm{NAG}$ & 16 & 26 & 22 & 0 \\
\hline
\end{tabular}

${ }^{1} \mathrm{NPG}=$ native perennial grass, $\mathrm{NAG}=$ native annual grass, $\mathrm{IPG}=$ introduced perennial grass, $\mathrm{IAG}=$ introduced annua grass, NPF = native perennial forb, NAF = native annual forb, IPF = introduced perennial forb, LAF = introduced annual forb.

subtracted from pre-tracking fractional aerial intercept and then subtracted from 1 to quantify the amount of vertical vegetation structure remaining after tracking. This procedure was done to reduce the influence of pre-tracking block and treatment differences in fractional aerial intercept. The results of the post-tracking correlations indicated that the block effects were adequately controlled to allow for a valid comparison of treatment effects. This term shall simply be known as fractional aerial intercept.

\section{Threshold Wind Speed}

The mean threshold wind speed was measured for each treatment at a height of $75 \mathrm{~mm}$. A Mixed Effects Model for Analysis of Variance (hereafter known as the Mixed Effects Model) was used with the General Linear Models procedure (GLM) in the SAS/STAT Version 6.12 (SAS Institute Inc. 1990) to compare differences in treatment means for threshold wind speed. Regression analysis was used to examine the effects of fractional aerial intercept on threshold wind speed.

\section{Surface Material Removal}

The amount of soil and litter removed by the wind stream was estimated from the mass of soil and litter captured by the inline filters at the rear of the wind tunnel. Total removed material mass, coarse litter mass, fine material mass, and soil mass were modeled versus treatment to examine the effect of tracking on these soil surface features. Regression analysis was used to examine the effects of fractional aerial intercept on total removed material mass.

\section{Correlations}

Post-tracking correlations were done to examine changes in vegetation parameters versus number of passes. Correlations were also done to determine if relation- ships existed between vegetation parameters and threshold wind speed. Specific correlations examined for these were: threshold wind speed versus number of passes, block effects, and fractional aerial intercept.

\section{Results}

\section{Community Composition}

The species composition for the study site was dominated by annual and perennial grasses and annual forbs from 0.1 meters to 0.3 meters in height. Mean plant cover in the study area was $30 \%$ native perennial grasses, $16 \%$ annual native grasses, $18 \%$ exotic annual grasses, $13 \%$ native annual forbs, and $18 \%$ exotic annual forbs (Table 2).

\section{Post-Tracking Comparisons}

Figure 1 shows the results of the posttracking comparisons. A single pass with the M1 did not significantly reduce fractional aerial intercept. However, multiple passes of 2,4 , and 8 resulted in significant reductions in fractional aerial intercept when compared to the control and 1 pass. In addition, the treatment with 8 passes had significantly less fractional aerial intercept than 2 passes.

\section{Threshold Wind Speed}

Results indicated that increasing number of vehicle passes resulted in significant decreases in threshold wind speed for each treatment (Fig. 2). Particle entrainment into the air stream was not achieved for untracked areas, even at the highest wind speeds attainable by the wind tunnel.

Predictive models were developed using regression analysis to examine the effect of post-tracking vegetation parameters on threshold wind speed. Post-tracking fractional aerial intercept was modeled with 


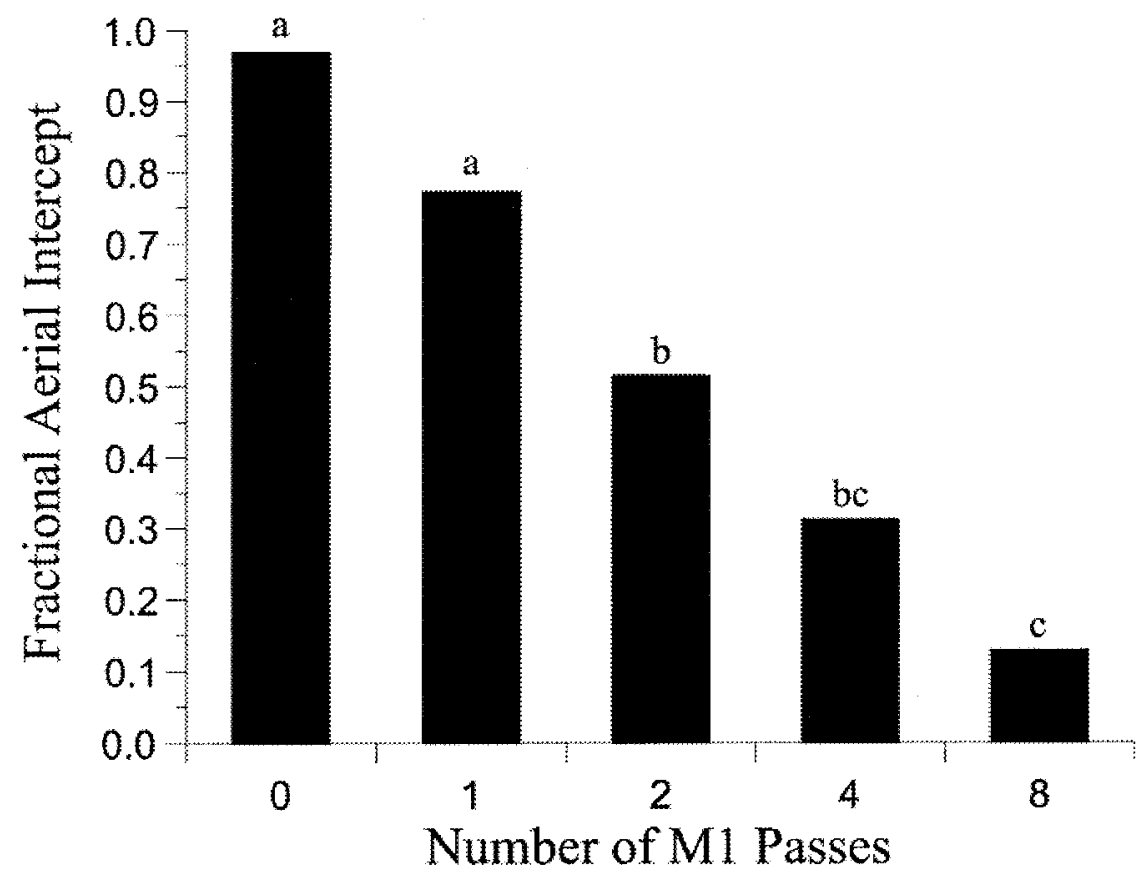

Fig. 1. Post-tracking fractional aerial intercept. The same letter indicates no significant differences at $p \leq 0.05(n=15)$.

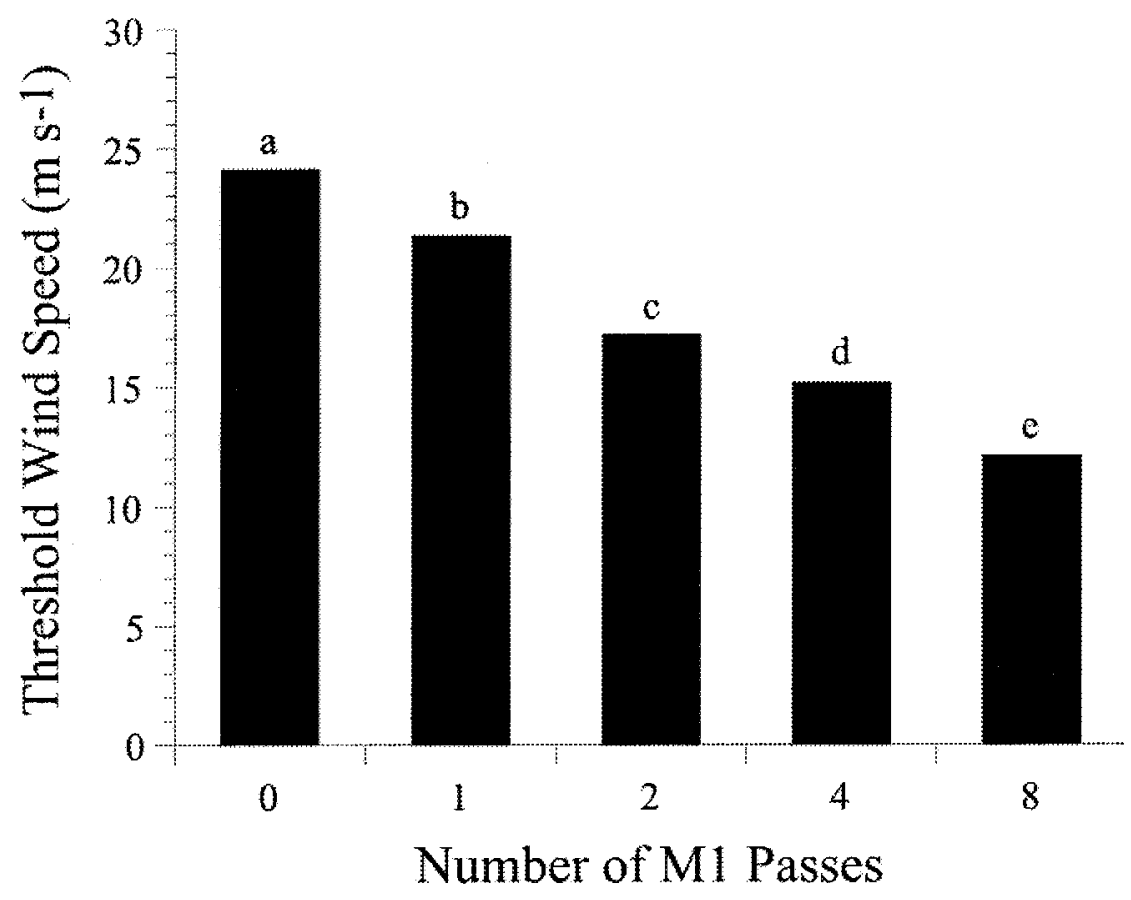

Fig. 2. Mean threshold wind speeds. The same letter indicates no significant differences at $p$ $\leq 0.05(n=150)$. threshold wind speed. The model for the effect of fractional aerial intercept predicts that threshold wind speed increases with an increase in fractional aerial intercept (FAI):

Threshold Wind Speed $\left(\mathrm{m} \mathrm{sec}^{-1}\right)=$ $11.53+13.42$ (FAI) $\mathrm{R}^{2}=0.87$

\section{Soil Removal}

Results from the material mass measurements indicated that as the number of M1 passes increased, the total mass of removed material significantly increased (Fig. 3). However, after sieving the total removed material into coarse litter, fine material, and soil size classes, it was found that each size class did not follow this pattern. Examination of the trend in the mass of the coarse litter portion showed that 1 and 2 passes resulted in significantly higher mass of coarse litter removed compared to the untracked area. Four and 8 passes did not significantly increase coarse litter mass above the mass associated with 2 passes but were significantly higher than 0 and 1 pass. One, 2, and 4 passes resulted in significantly greater fine material mass compared with no tracking. Fine material was highest after 8 passes. The mass of the soil portion was also successively greater as the number of passes increased.

Predictive models were also developed using regression analysis to examine the effects of fractional acrial intercept on total mass of removed material. Total removed material mass is predicted to decrease as fractional aerial intercept increases:

$$
\begin{aligned}
& \text { Total Removed Material Mass } \\
& \left(\mathrm{g} / 0.46 \mathrm{~m}^{2}\right)^{1}=173.74-186.03(\mathrm{FAI}) \\
& \mathrm{R}^{2}=0.93
\end{aligned}
$$

\section{Potential Soil Loss for Orchard Training Area}

Potential soil loss resulting from simulated tracking were developed and are shown in Table 3 . These predictions pertain to level grassland areas similar to the area used for this study. These predictions are based upon the wind speed of $24 \mathrm{~m}$ $\sec ^{-1}$ at $75 \mathrm{~mm}$ that was used during soil loss testing.

\section{Correlations}

Correlations between the number of M1 passes and blocks and fractional aerial intercept were conducted. Fractional aerial intercept was negatively correlated with the increase in M1 passes (Table 4). No 


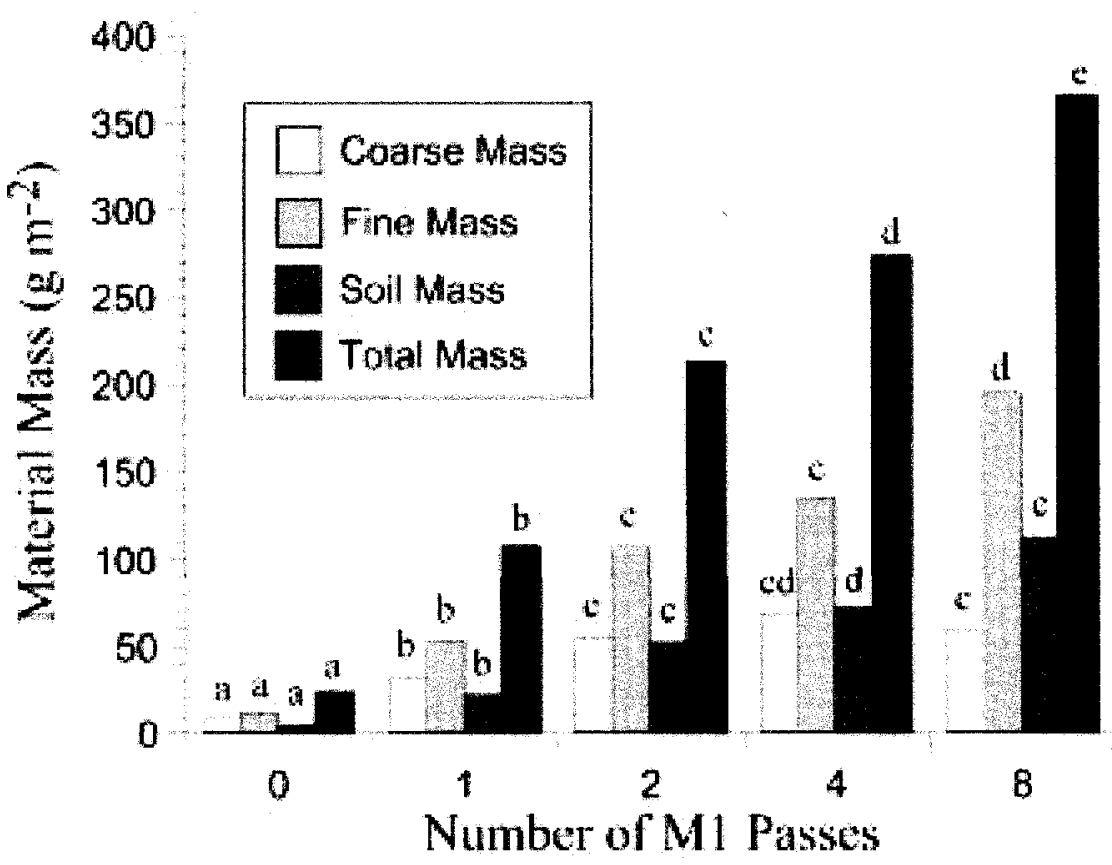

Fig. 3. Mean material mass for total mass and size class. The same letter within a weight class indicates no significant differences at $p \leq 0.05(n=145)$.

tain to level grassland areas similar to the area used for this study. These predictions are based upon the wind speed of $24 \mathrm{~m}$ $\mathrm{sec}^{-1}$ at $75 \mathrm{~mm}$ that was used during soil loss testing.

\section{Correlations}

Correlations between the number of $\mathrm{M} 1$ passes and blocks and fractional aerial intercept were conducted. Fractional aerial intercept was negatively correlated with the increase in M1 passes (Table 4). No significant correlations existed between block and fractional aerial intercept.

\section{Discussion}

\section{Effects of Tracking on Vegetation Structure and Soil Erosion}

Results indicated that particle entrainment into the air stream was not achieved for untracked areas, even at the highest wind speeds attainable by the wind tunnel. Threshold wind speed after 1 pass was significantly lower than untracked areas. This implied 2 things: 1) the untracked areas were characterized by relatively stable soil surfaces even at high wind speeds, and 2) 1 pass was sufficient to initiate significantly less stable soil surface conditions as compared with untracked areas. Work by Chepil (1956) and Gillette et al. (1980) found that material; though there was not a significant decrease in vertical vegetation struceffect of disrupting the stable soil surface. Once the surface was disrupted after 1 pass, the immediate result was the decrease in threshold wind speed and an increase in the mass of total removed parentheses indicates whether or not this correlation is significant. ture. The second crucial effect was the destruction of the vertical vegetation structure, which is evident after a comparison of the 4 tracking intensities. Vertical vegetation structure was compressed, detached, crushed into finer particles, and removed from the soil surface. As tracking intensity increased, so did the loss of vertical vegetation structure.

Past research by Marshall (1971), Gillette and Stockton (1989), Musick and Gillette (1990), and Raupach et al. (1993) concluded that vegetation structure acts as an aerodynamic roughness element with respect to the air stream. Results from this study indicated that vertical vegetation roughness elements decreased with track ing intensity after 1 pass. This decrease in the vertical vegetation roughness elements resulted in an increase in wind stress on the surface, which led to a decrease in threshold wind speed and increased rates of erosion.

The results of the predictive models also corroborated these findings. Vertical vegetation structure was shown to be the best predictor for the decrease in threshold wind speed with a strong correlation of 0.93 . Vertical vegetation structure was also the best predictor for the increase in surface material removed with an $R^{2}=$ 0.93 . It may be concluded from these models that the most significant effect of tracking on threshold wind speed and soil loss is the destruction and removal of vertical vegetation structure. However, it would not be entirely accurate to separate the effect of soil surface disruption from the destruction of vertical vegetation structure. There is probably an interactive, synergistic effect of these results on threshold wind speed and soil loss. As tracking intensity increased, the tank treads churned up the soil and began to entrench into the soil profile. Greater soil loss also resulted because of greater soil exposure.

Table 4. Top values represent Pearson Correlation Coefficients for number of passes and block designation vs. fractional aerial intercept. Numbers in Parentheses represent p-values.

\begin{tabular}{lccc} 
& $\begin{array}{c}\text { Threshold Wind } \\
\text { Speed }\end{array}$ & Soil Mass & $\begin{array}{c}\text { Fractional Aerial } \\
\text { Intercept }\end{array}$ \\
\hline M1 passes & -0.86 & 0.84 & -0.87 \\
Block -0.31 & $(0.0001)$ & $(0.0001)$ & $(0.0001)$ \\
Fractional Aerial & 0.31 & -0.21 & $(0.45)$ \\
Intercept & $(0.26)$ & $(0.54)$ & $* * *$ \\
\hline
\end{tabular}

The variables within the columns are assumed to be dependent upon the increase of the vegetation parameters. A positive top value within each cell indicates that the dependent variable increases as the independent variable increases. A negative value indicates that the dependent variable decreases as the independent variable increases. The lower number in 


\section{Comparisons of Threshold Wind Speed Results with Local Wind Speeds}

This discussion would not be complete without a comparison of the threshold wind speeds with the average wind speeds recorded for this area. Wind speeds for the years 1964-1995, 1995-1997, and 1996 are represented in Table 5 . These wind speeds were measured at 10 meters in height at Boise Municipal Airport, Boise, Ida.

Table 5. Average, maximum, and minimum wind speeds recorded at Boise Municipal Airport for years 1964-1995, 1995-1997, and 1996. Wind speeds were measured at a height of 10 meters.

\begin{tabular}{lccc}
\hline \hline & \multicolumn{3}{c}{ Wind Speed } \\
Year & Average & Maximum & Minimum \\
\hline & $\cdots \cdots-$ & $\left(\mathrm{m} \mathrm{sec}^{-1}\right)$ & $\cdots \cdots$ \\
$1964-1995$ & 3.74 & 4.52 & 3.34 \\
$1995-1997$ & 3.46 & 3.50 & 3.39 \\
1996 & 3.50 & 8.31 & 1.01 \\
\hline
\end{tabular}

The threshold wind speed necessary to initiate wind erosion for the 8-pass treatment was $12.06 \mathrm{~m} \mathrm{sec}^{-1}$. Though this wind speed is well above the average and maximum wind speeds for the recorded years, it is not unrealistic to assume gusts as high or higher than $15 \mathrm{~m} \mathrm{sec}^{-1}$ on occasion. If this is the case, then areas subjected to 4 or greater passes may experience soil erosion during these rare events. It is also necessary to keep in mind that even a small precipitation event would be enough to aggregate surface soil particles into a rain crust that would be more resistant to wind erosion than a surface without a rain crust.

\section{Conclusions and Recommendations}

The results of this study indicated that tracking by the M1A2 resulted in 2 crucial effects that contributed to increased soil erosion. Tracking has the immediate effect of disrupting the stable soil surface and the destruction of the vertical vegetation structure with increased tracking; which is evident after a comparison of the 4 tracking intensities. Removal of momentum retardant vegetation canopy with tracking intensities greater than one pass resulted in greater drag exerted on the surface of the soil which decreased threshold wind speed and removed greater amounts of soil.

Based upon these results and the likelihood of local wind speeds exceeding $15 \mathrm{~m}$ $\sec ^{-1}$, the critical tracking threshold for the M1A2 battletank at Orchard Training Area for grassland and forb dominated plant communities was concluded to be 4 passes. Tracking levels greater than or equal to four passes may result in a critical decrease in canopy cover that is necessary to protect the tracked surface from gusts of wind exceeding 15 to $17 \mathrm{~m} \mathrm{sec}^{-1}$.

Turns were not simulated in this study. Observations at the time of tracking showed that a single turn often had the result of stripping off the vertical vegetation structure, the upper 15 to 38 centimeters of the soil profile, and the creation of deep ruts. In effect, 1 turn was equivalent to greater than or equal to 8 passes in terms of vegetation and soil surface disruption. We hypothesize that 1 turn creates a highly erodible soil surface that would have threshold wind speeds similar to an area experiencing 8 or more straight passes. Further study of this aspect of tracked vehicle training exercises is necessary in order to gain a better understanding of the effects of tracked vehicle maneuvers on vegetation and soil surfaces.

Based upon these conclusions, it is recommended that special attention be paid to the management of the vertical vegetation structure. During training activities, it is suggested that activities resulting in multiple passes on the same area be minimized with the use of hardtop roads. Sharp turns that scrape off the vegetation structure and surface soil horizons should also be minimized. Any off-road use of the M1A2 should occur within the critical tracking threshold of 4 consecutive passes.

\section{Literature Cited}

Bagnold, R.A. 1941. The Physics of Blown Sand and Desert Dunes. Methuen \& Co., Ltd. London.

Bonham, C.D. 1989. Mcasurements for Terrestrial Vegetation. John Wiley \& Sons, New York.

Chepil, W.S. 1945. Dynamics of wind erosion: III. The transport capacity of the wind. Soil Sci. 60:475-480.

Chepil, W.S. 1956. Influence of moisture on soil erodibility by wind. Proc.-Soil Sci. Soc. Amer. 20:288-292.

Findlater, P.A., D.J. Carter, and W.D. Scott. 1990. A model to predict the effects of prostrate ground cover on wind erosion. Aust. J. Soil Res. 28:609-622.

Foss, C.F. ed. 1988. Jane's Armour and Artillery, 1987-1988, $8^{\text {th }}$ ed. Jane's Pub. Co. Ltd., London.

Fryrear, D.W. 1985. Soil cover and wind erosion. Trans. ASAE. 28:781-784.
Gillette, D. 1978. Tests with a portable wind tunnel for determining wind erosion threshold velocities. Atmospheric Environ. 12:2309-2313.

Gillette, D.A. 1988. Threshold friction velocities for dust production for agricultural soils. J. Geophys. Res. 93: No. D10. 12,645-12,662.

Gillette, D.A. and P.H. Stockton. 1989. The effect of non-erodible particles on wind erosion at erodible surfaces. J. Geophys. Res. $94: 12,88512,893$.

Gillette, D., J. Adams, A. Endo, D. Smith, and R. Kihl. 1980. Threshold velocities for input of soil particles into the air by desert soils. J. Geophys. Res. 85:5621-5630.

Iversen, J.D., R. Greeley, J.B. Pollack, and B.R. White. 1973. Simulation of Martian eolian phenomena in the atmospheric wind tunnel, p. 191-213. In: AIAA/NASA/ASTM/ IEMS $7^{\text {th }}$ Space Simulation Conference NASA SP-336.

Lyles, L. and R.L Schrandt. 1974. How aerodynamic roughness elements control sand movement. Trans. ASAE. 17:134-139.

Marshall, J. 1971. Drag measurements in roughness arrays of varying density and distribution. Agr. Meteorol. 8:269-292.

Marticorena, B. G., G. Bergametti, D. Gillette, and J. Belnap. 1997. Factors controlling threshold friction velocity in semiarid and arid areas of the United States. J. Geophys Res. 102(D19):23,277-23,287.

Musick, H.B. and D.A. Gillette. 1990. Ficld evaluation of relationships between a vegetation structural parameter and sheltering against wind erosion. Land Degradation and Rehab. 2:87-94.

Phillips, M. A. 1980. Force balance model for particle entrainment in a fluid stream. J. Phys. 13:221-233.

Raupach, M.R., D.A. Gillette, J.F. Leys. 1993. The effect of roughness elements on wind erosion threshold. J. of Geophys. Res. 98:No. D2: 3023-3029.

SAS. 1990. [computer program]. Version 6.11. SAS Inst. Inc. Cary, N.C

Stockton, P.H. and D.A. Gillette. 1990. Field measurement of the sheltering effect of vegetation on erodible land surfaces. Land Degradation Rehab. 2:77-85.

Williams, J.D., J.P. Dobrowolski, N.E. West, and D.A. Gillette. 1995. Microphytic crust influence on wind erosion. Trans. ASAE. 38:131-137

Wood, G.P., W. Weaver, and R. Henry. 1974. The Minimum Free-stream Wind for Initiating Motion of Surface Material on Mars. NASA Tech. Memorandum. NASA TM X-71959, NASA Langley Res. Center, Hampton, Virg. 